\title{
Biogas/Biomethane Quality and Requirements for Combined Heat and Power (CHP) Units/Gas Grids with a Special Focus on Siloxanes-a Short Review
}

\author{
Grzegorz Piechota \\ GPCHEM Laboratory of Biogas Research and Analysis \& Incubator of Technology, Torun, Poland \\ Email: gp@gpchem.pl
}

Received: 27 June 2021; Revised: 14 September 2021; Accepted: 16 September 2021

\begin{abstract}
The presence of siloxanes in biogas and biomethane is a major barrier to use them as renewable energy sources in Combined Heat and Power (CHP) units and national grids systems. Siloxanes in the shape of methyl siloxanes (incl. L2, L3, L4, D3, D4, D5, D6), Trimethylsilanol (TMSOH), as well as other contaminants such as $\mathrm{H}_{2} \mathrm{~S}$, $\mathrm{NH}_{3}$, relative Humidity ( $\mathrm{rH}$ ), halogenated compounds (including organic chlorine and fluorine), and Volatile Organic Compounds (VOCs) presented in biogas upgraded to biomethane quality are detrimental to engines, turbines and gas grids, therefore it is necessary to remove them before its high-value utilization. Under the oxidation, process siloxanes are converted into microcrystalline silicon dioxide $\left(\mathrm{SiO}_{2}\right)$ deposits that can shorten the lifetime of the engine and affect the gas grids. The review presents the actual requirements of biogas and biomethane quality in context to their utilization in CHP units and national gas grids. Moreover, the methods of siloxanes removal based on adsorption, absorption, cryogenic condensation, membranes, and biofiltration are described.
\end{abstract}

Keywords: biogas, biomethane, siloxanes, CHP units, biogas purification

\section{Introduction}

Nowadays the biomethane is gaining popularity. ${ }^{1}$ The purification of biogas from siloxanes and its upgrading to biomethane becomes a real alternative for commercial biogas utilization. Moreover, several standards are describing the purity of biogas and biomethane originated from biogas upgrading. ${ }^{2}$ On the other hand, the combustion of biogas/ biomethane under the oxidation process is converted to carbon dioxide and water and in a natural way, the emission impact ${ }^{3}$ is reduced. As the European Biogas Association (EBA) reported, biogas and biomethane have significant and growing contributions to achieve the European Union (EU) climate-neutrality by 2050 as well as, biogas industries have a significant impact on worldwide greenhouse gas reduction-potential to reduce Green House Gas (GHG) emissions is estimated by $10-13 \%{ }^{4}$

The review provides the parameters and requirements of biogas and biomethane in context to its utilization and direct injection to national gas grids systems. Moreover, the paper describes critical parameters of biogas quality in terms of manufacturer limitations and guarantees. The presented work describes the most popular biogas purification technologies based on physical, chemical, and biological processes with a special focus on siloxanes.

Copyright (C2021 Grzegorz Piechota

DOI: https://doi.org/10.37256/sce.3120221015

This is an open-access article distributed under a CC BY license

(Creative Commons Attribution 4.0 International License)

https://creativecommons.org/licenses/by/4.0/ 


\subsection{Parameters of biogas/biomethane as biofuel used in CHP units gas grids}

The use of biogas/biomethane as a biofuel in CHP units producing electricity and heat requires a prior detailed analysis of the biogas with respect to the qualitative energy parameters of the raw material and the content of its pollutants. Biogas/biomethane used as a fuel in power generation units or injected into national gas grids needs to fulfill the strictly defined criteria of its utilization, in accordance with the manufacturer's guidelines or national grids limitations. ${ }^{5}$ The unit manufacturer's guidelines describe in detail the biogas parameters that qualify the gas as a fuel of a given category: low, medium, and high. ${ }^{6}$ The classification of biogas into one of the above categories has a direct impact on the engine's operating time between mandatory maintenance intervals, while at the same time showing an indirecteconomic-character related to the cost of its servicing, replacement of its worn parts or lubricating oil. The frequency of mandatory technical maintenance of the unit depends mainly on the manufacturer of the power generation units, but most manufacturers declare that the mandatory maintenance interval should be carried out once every 4 months of uninterrupted operation of the unit. In the case of power generation units or CHP units, the period of the obligatory maintenance interval depends only on the quality of the raw material fed to the engine, respectively according to the following table: Low: mandatory service every 1000 hours of operation of the unit, Medium: mandatory service every 3000 hours of operation of the unit, High: mandatory service every 5000 of operation of the unit. ${ }^{6}$

Determination of the energy value of the raw material and the level of classification of the biogas is important investment information based on which the model, the type, and the power of the unit are evaluated, and a maintenance schedule is established together with a cost estimate. Tables 1, 2, and 3 below present detailed guidelines for the quality of the propellant fed to the unit for the power generating units of leading European manufacturers. ${ }^{6}$ The following parameters apply also to those systems that are equipped with CHP with a small and micro scale, but the range of the pollution limits is significantly weaker.

Table 1. Boundary parameters for biogas used in the CHP units ${ }^{6}$

\begin{tabular}{|c|c|c|}
\hline Parameter & Unit & Limit \\
\hline \multirow{3}{*}{ Methane content } & $\begin{array}{c}\text { Calorific value } \\
\mathrm{kWh} / \mathrm{m}^{3}\end{array}$ & $>5$ \\
\hline & $\begin{array}{l}\text { Calorific value } \mathrm{H}\left[\mathrm{MJ} / \mathrm{m}^{3}\right] \\
\quad\left(0^{\circ} \mathrm{C}, 101,335 \mathrm{kPa}\right)\end{array}$ & $\mathrm{Wu}>18$ \\
\hline & Vol \% & $40-70,<90$ \\
\hline $\mathrm{H}_{2} \mathrm{~S}$ & ppm & $<200$ \\
\hline Total Sulphur & $\mathrm{mg} / \mathrm{m}^{3} \mathrm{~N}$ & $<200$ \\
\hline Halogens (Cl, Br, F, I) & $\mathrm{mg} / \mathrm{m}^{3} \mathrm{~N} \mathrm{CH}_{4}$ & $<80$ \\
\hline \multirow[t]{2}{*}{ Dust } & $\mathrm{mg} / \mathrm{m}^{3} \mathrm{~N} \mathrm{CH}_{4}$ & $<10$ \\
\hline & grain $<5 \mu m$ & \\
\hline Oil mist (OM) & $\mathrm{mg} / \mathrm{m}^{3} \mathrm{~N} \mathrm{CH}_{4}$ & $<400$ \\
\hline VOCs & $\mathrm{mg} / \mathrm{m}^{3} \mathrm{~N} \mathrm{CH}_{4}$ & $<25$ \\
\hline Silicon content $(\mathrm{Si})$ & $\mathrm{mg} / \mathrm{m}^{3} \mathrm{~N} \mathrm{CH}_{4}$ & $<2$ \\
\hline Relative humidity & $\mathrm{rH} \% /{ }^{\circ} \mathrm{C}$ & $<80$ \\
\hline Ammonia & $\mathrm{mg} / \mathrm{m}^{3} \mathrm{~N} \mathrm{CH}_{4}$ & $<30$ \\
\hline Gas temperature & ${ }^{\circ} \mathrm{C}$ & $10<\mathrm{T}<30$ \\
\hline Oxygen content & $\%$ & $<2$ \\
\hline
\end{tabular}

The units in which the pollutants are described, i.e. $\mathrm{mg} / \mathrm{m}^{3} \mathrm{~N} \mathrm{CH}_{4}$ as well as $\mathrm{mg} / 10 \mathrm{kWh}$, are used alternately by the manufacturers and are equivalents. 
Table 2. Limiting parameters for biogas used in the Power Generation units ${ }^{6}$

\begin{tabular}{|c|c|c|}
\hline Parameter & Unit & Limit \\
\hline \multirow{2}{*}{ Methane content } & $\begin{array}{c}\text { Caloryfic value } \\
\mathrm{kWh} / \mathrm{m}^{3}\end{array}$ & $>5$ \\
\hline & Vol \% & $>50$ \\
\hline $\mathrm{H}_{2} \mathrm{~S}$ & $\mathrm{ppm} / 10 \mathrm{kWh}$ & $<1500$ \\
\hline $\begin{array}{l}\text { Sulphur which is not a } \\
\text { derivative of } \mathrm{H}_{2} \mathrm{~S}\end{array}$ & $\mathrm{mg} / 10 \mathrm{kWh}$ & - \\
\hline Halogens (Cl, Br, F, I) & $\mathrm{mg} / 10 \mathrm{kWh}$ & $<100$ \\
\hline \multirow[t]{2}{*}{ Dust } & $\mathrm{mg} / 10 \mathrm{kWh}$ & $<10$ \\
\hline & grain 3-10 $\mu \mathrm{m}$ & \\
\hline $\mathrm{OM}$ & $\mathrm{mg} / 10 \mathrm{kWh}$ & $<400$ \\
\hline Silicon compounds ( $\mathrm{Si}$ ) & $\mathrm{mg} / 10 \mathrm{kWh}$ & $<20$ \\
\hline Relative humidity & $\mathrm{rH} \% /{ }^{\circ} \mathrm{C}$ & $<80$ \\
\hline Ammonia & $\mathrm{mg} / 10 \mathrm{kWh}$ & $<30$ \\
\hline
\end{tabular}

Table 3. Pollutant limit parameters for quality classification of biogas used in the CHP units ${ }^{6}$

\begin{tabular}{|c|c|c|c|}
\hline Gas quality/Parameters & Low & Medium & High \\
\hline Sulphur (total S) per $10 \mathrm{kWh}$ & below $2200 \mathrm{mg}$ & below $440 \mathrm{mg}$ & below $15 \mathrm{mg}$ \\
\hline $\begin{array}{l}\text { Hydrogen sulphide (total } \mathrm{H}_{2} \mathrm{~S} \text { ) } \\
\text { with reference to } 10 \mathrm{kWh}\end{array}$ & $\begin{array}{c}\text { above } 1500 \mathrm{ppm} \\
\text { (corresponds to } 0.15 \text { vol. \%) }\end{array}$ & $\begin{array}{l}\text { below } 300 \mathrm{ppm} \\
\text { (corresponds to } 0.03 \text { vol. \%) }\end{array}$ & $\begin{array}{l}10 \mathrm{ppm} \\
\text { (corresponds to } 0.001 \text { vol. \%) }\end{array}$ \\
\hline Chlorine (total $\mathrm{Cl}$ ) per $10 \mathrm{kWh}$ & below $100 \mathrm{mg}$ & below $20 \mathrm{mg}$ & below $2 \mathrm{mg}$ \\
\hline Fluorine (total F) per $10 \mathrm{kWh}$ & below $50 \mathrm{mg}$ & below $10 \mathrm{mg}$ & below $1 \mathrm{mg}$ \\
\hline $\begin{array}{l}\text { Chlorine and fluorine (total CI and F) } \\
\text { per } 10 \mathrm{kWh}\end{array}$ & below $100 \mathrm{mg}$ & below $20 \mathrm{mg}$ & below $2 \mathrm{mg}$ \\
\hline Ammonia (total $\mathrm{NH}_{3}$ ) per $10 \mathrm{kWh}$ & below $150 \mathrm{mg}$ & below $30 \mathrm{mg}$ & below $2 \mathrm{mg}$ \\
\hline Humidity & below $80 \%$ & below $50 \%$ & below $50 \%$ \\
\hline Silicon compounds (VMSs) per $10 \mathrm{kWh}$ & below $20 \mathrm{mg}$ & below $1 \mathrm{mg}$ & $0 \mathrm{mg}$ \\
\hline Dust content. Total per $10 \mathrm{kWh}$ & below $10 \mathrm{mg}$ & below $2 \mathrm{mg}$ & below $0.5 \mathrm{mg}$ \\
\hline Dust granularity & above $3 \mu \mathrm{m}$ & above $2 \mu \mathrm{m}$ & above $2 \mu \mathrm{m}$ \\
\hline $\begin{array}{l}\text { Higher hydrocarbons and tars } \\
\text { above } \mathrm{C} 5 / \text { below } \mathrm{C} 10 \text { per } 10 \mathrm{kWh}\end{array}$ & below $3000 \mathrm{mg}$ & below $600 \mathrm{mg}$ & below $100 \mathrm{mg}$ \\
\hline higher/equal C10 per $10 \mathrm{kWh}$ & below $250 \mathrm{mg}$ & below $50 \mathrm{mg}$ & below $10 \mathrm{mg}$ \\
\hline higher/equal C12 per $10 \mathrm{~kW}$ & below $0.5 \mathrm{mg}$ & $0 \mathrm{mg}$ & $0 \mathrm{mg}$ \\
\hline
\end{tabular}

Apart from its energy properties, biogas has a very complex organic matrix. This matrix contains over 400 different compounds of organic origin-from simple hydrocarbons to complex terpene derivatives. ${ }^{7}$ On the other hand, the presence of chemical compounds such as hydrogen sulphide, ammonia, halogens, Oil Mist (OM)-hydrocarbons with more than 10 carbon atoms in the molecule, silanes, methyl siloxanes, or trimethylsilanol (TMSOH)-has a significant impact on the efficiency of biogas energy production. Most organic pollutants which are present in biogas are formed by the decomposition of substances contained in organic matter and are of different polarity, water-solubility, volatility, or vapor pressure, which creates particular difficulties in their control, determination, or removal. Besides, when considering the use of biogas as a fuel in biogas engines, the influence of the matrix and the effect of gas impurities on the efficiency of the extracted energy must be taken into account, both technologically and economically. ${ }^{8}$ The content 
of more or less problematic compounds in biogas leaves its mark in the form of reduced efficiency of the unit, shorter intervals between compulsory maintenance, or plant downtime due to the replacement of internal parts of the plant or the unit. The requirements for biomethane are listed in Table 4.

Table 4. Biomethane injected to gas grid requirements ${ }^{9,10}$

\begin{tabular}{|c|c|c|}
\hline Parameter & Biomethane & EU Standards \\
\hline Higher heating values $\left(\mathrm{MJ} / \mathrm{Nm}^{3}\right)$ & $37.2 \pm 0.6$ & \\
\hline Wobbe index $\left(\mathrm{MJ} / \mathrm{Nm}^{3}\right)$ & $50.2 \pm 1.9$ & \\
\hline Methane number (MN) & $95 \pm 4.2$ & $>65.0$ \\
\hline Relative density & $0.54 \pm 0.02$ & \\
\hline $\mathrm{CH}_{4}(\mathrm{v} / \mathrm{v} \%)$ & $97.4 \pm 2.4$ & $>45.0$ \\
\hline $\mathrm{CO}_{2}(\mathrm{v} / \mathrm{v} \%)$ & $1.1 \pm 0.3$ & $<45.0$ \\
\hline $\mathrm{O}_{2}(\mathrm{v} / \mathrm{v} \%)$ & $0.1 \pm 0.05$ & $<0.1$ \\
\hline $\mathrm{N}_{2}(\mathrm{v} / \mathrm{v} \%)$ & $0.05 \pm 0.01$ & \\
\hline $\mathrm{H}_{2}(\mathrm{v} / \mathrm{v} \%)$ & $0.05 \pm 0.02$ & $<2.0$ \\
\hline $\mathrm{H}_{2} \mathrm{~S}(\mathrm{ppm})$ & $88.1 \pm 2.0$ & \\
\hline Mercaptans (as S) $\left(\mathrm{mg} / \mathrm{Nm}^{3}\right)$ & $0.2 \pm 0.1$ & \\
\hline Total S $\left(\mathrm{mg} / \mathrm{Nm}^{3}\right)$ & $88.1 \pm 2.2$ & \\
\hline $\mathrm{CO}\left(\mathrm{mg} / \mathrm{Nm}^{3}\right)$ & $0.02 \pm 0.01$ & \\
\hline Siloxanes $\left(\mathrm{mg} / \mathrm{Nm}^{3}\right)$ as VMSs & $0.05 \pm 0.02$ & $<0.79$ \\
\hline $\mathrm{NH}_{4}\left(\mathrm{mg} / \mathrm{Nm}^{3}\right)$ & $1.1 \pm 0.1$ & \\
\hline $\operatorname{VOCs}\left(\mathrm{mg} / \mathrm{Nm}^{3}\right)$ & $63 \pm 5.9$ & \\
\hline Fluorine $\left(\mathrm{mg} / \mathrm{Nm}^{3}\right)$ & $9.2 \pm 1.0$ & \\
\hline Chlorine $\left(\mathrm{mg} / \mathrm{Nm}^{3}\right)$ & $80.0 \pm 5.2$ & \\
\hline Dew point $(\%)$ at $27^{\circ} \mathrm{C}$ & $22.2 \pm 0.1$ & $>90.0$ \\
\hline
\end{tabular}

\section{Siloxanes in biogas/biomethane}

The influence of silicon compounds and other impurities present in biogas on energy and heat production in the process of cogeneration. ${ }^{11}$ The presence of volatile silicon compounds in biogas/biomethane poses very serious problems for biogas power generation units and national gas grids for operators. During the process of biogas/ biomethane utilization, a number of chemical reactions involving volatile silicon compounds take place in the units. The main reaction of siloxanes in the biogas is oxidation, where the final product in the shape of the microcrystalline deposit of $\mathrm{SiO}_{2}$ is formed. ${ }^{7}$ The microcrystalline deposit from the combustion chamber is characterized by the presence of elements such as calcium, bismuth, zinc, and Sulphur, in addition to a predominance of $\mathrm{SiO}_{2}$. Most of the analyzed motor deposits are white or slightly grey in color. The morphological structure of the surface varies depending on where it is formed. We distinguish between deposits with different physical structures, ranging from perfectly smooth through clusters to completely heterogeneous. Microcrystalline $\mathrm{SiO}_{2}$ in its various forms perfectly covers the internal parts of the engine, sometimes with a layer of several millimetres, which is difficult to be removed. The tendency to form a thin microcrystalline film depends mainly on the internal combustion chamber temperature, the pressure inside the chamber, the catalyst used, or the type of surface exposed to adhesion. In addition, the layer of microcrystalline $\mathrm{SiO}_{2}$ 
deposited on the internal parts of the unit acts as an insulator, preventing proper cooling of the unit, which consequently leads to overheating of the running engine components. The most exposed to microcrystalline sludge are the following: combustion chambers, valves, valve seats, cylinder crowns, cylinder walls, piston crowns, and pans-these are also the hottest parts of a running engine. In the case of biomethane, siloxanes cause damage to gas grids. ${ }^{7,10}$

Table 5. Physical and chemical properties of siloxanes ${ }^{12}$

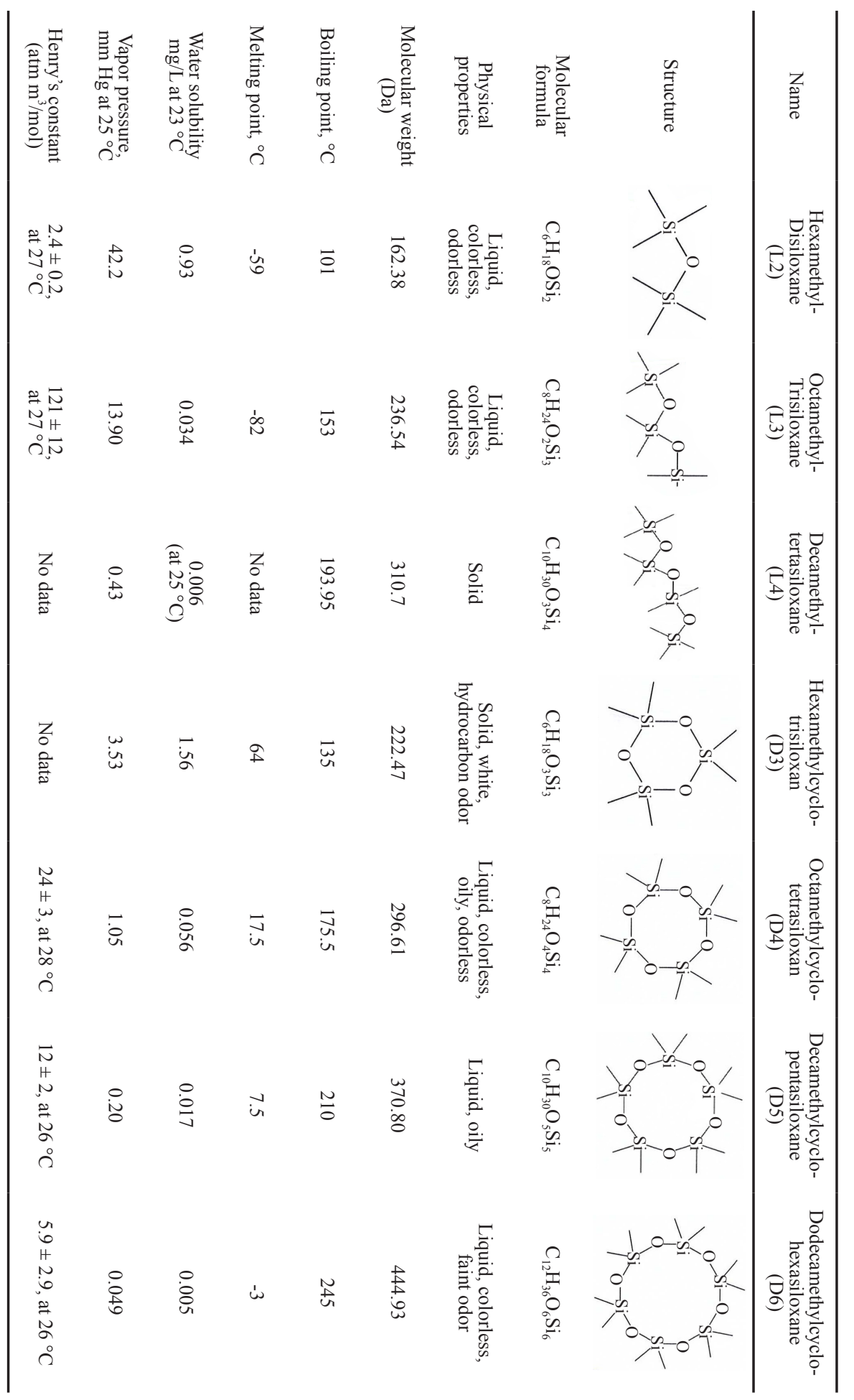


The formation process of microcrystalline precipitate during the oxidation of VMSs inside the generator is described in two steps. In the first stage, in a combustion chamber, volatile methyl siloxanes are oxidized under high temperature and pressure to an amorphous, liquid form of microcrystalline glass. The second stage is the crystallization process, which takes place after the engine has cooled down; during this stage, with the slow process of cooling, the amorphous form crystallizes, covering the internal parts of the unit with a thin deposit layer. The deposit does not spread regularly inside the unit; its occurrence depends mainly on the cooling rate of the internal parts of the unit. Most of the deposit is accumulated in the combustion chamber on pistons and cylinders, while its uneven distribution disturbs the combustion geometry of the chamber resulting in the disorderly knocking forces and, as a consequence, inhomogeneous combustion of biogas and, hence, generates higher emission of pollutants into the atmosphere.

At the same time, other pollutants present in biogas, such as oil mist, halogens, hydrogen sulphide, dissolve in the $\mathrm{rH}$ present in biogas, forming organic and inorganic acids $\left(\mathrm{H}_{2} \mathrm{~S}_{\mathrm{aq}}, \mathrm{HCl}_{\mathrm{aq}}, \mathrm{HF}_{\mathrm{aq}}\right)$, which as being present in the engine oil, drastically reduce its lubricating properties. In Table 5 physical and chemical properties of siloxanes presented in biogas/biomethane are presented. ${ }^{12}$

In the biomethane context, the initially pre-treated biogas (with low humidity) requires strong purification to be forwarded to the membrane upgradation system. Moreover, it must be taken into account that there are several local and EU standards to describe the purity of biomethane originating from biogas upgrading, which refers to the limitation of biomethane impurities in detail..$^{10}$ As the EBA reports, biogas and biomass industries have a significant and growing role in achieving climate neutrality by 2050 . These industries significantly impact worldwide greenhouse gas reduction: Their potential to reduce greenhouse gas emissions is estimated to be around 10-13\%. Moreover, upgrading biogas to biomethane serves as an example to understand the concept of "short carbon cycle". ${ }^{10}$

\section{Removal of volatile methyl siloxanes from biogas/biomethane}

Describing the methods for the removal of Volatile Methyl Siloxanes (VMSs) from biogas/biomethane, several commonly used techniques were taken into account. They include the occurring biological, physical, or chemical phenomena, as well as the physical and chemical properties of VMSs. ${ }^{13}$

The correlations between the physicochemical properties of VMSs and the physical and biological phenomena have been presented below. The commonly used methods for removing VMSs from biogas are based on them.

Since 2020, it could have been found in the literature that there are three commercial concepts describing the proposals of silica-contaminants solutions based on absorption and adsorption technologies. ${ }^{14}$ However, the most popular and common applied technologies for silica-contaminants removal being in common use are based on adsorption on activated carbon.

\subsection{Removal of VMSs based on the adsorption}

One of the most popular methods for removing VMSs is based on the phenomenon of physical adsorption of methylsiloxane molecules on the inner and outer surfaces of adsorbent materials, which largely depends on the porosity of the adsorbent. Figure 1 presents a classification of adsorbents commonly used in the process of methylsiloxane removal from biogas due to their chemical structure. Adsorption on active or activated carbon is one of the most commonly used biogas purification technology. However, the adsorption process strongly depends on the properties of used carbons. In general, the adsorption on porous material is strongly associated with its surface area and type-size of pore. ${ }^{15}$ The important issue has been noticed in the works of Ajhar et al. ${ }^{13}$ They reported that the absorption process of siloxanes on active/activated carbon depends on siloxanes concentration, type of active carbon impregnation, the water content of biogas, and temperature. ${ }^{13}$

Further adsorbents commonly used in biogas purification technology include carbon-based sorbents such as activated carbon, graphite, or coke nutshells. Considering the most technologically common activated carbon, it is characterised by a well-developed specific surface area of up to $1600 \mathrm{~m}^{2} / \mathrm{g}$ and a highly developed porous structure. It is a very universal sorbent, used extensively in biogas treatment systems with VMSs. However, it does not entirely account for its advantages and more specifically its superiority over other silicon-based adsorbents. Its main disadvantage is the lack of selectivity towards the adsorption of VMSs. As studies have revealed, the efficiency of adsorption of VMSs by 
activated carbons ranges from 5000 to $15000 \mathrm{mg}_{\text {siloxane }} / \mathrm{kg}$ of carbon, while maintaining the parameters of appropriate pressure and temperature, resulting in a real efficiency of the adsorption process at the level of $0.5-1.5 \%$ by weight of the filter used. Another technological barrier to using coal in the gas purification process is the requirement to remove excess moisture from the biogas stream entering the coal filter. Excessive moisture considerably reduces the efficiency of the filter by blocking the sorption surface with water molecules, which in turn considerably reduces the efficiency of the adsorption process. ${ }^{16}$ On the other hand, activated carbon that is additionally impregnated-by covering its surface with a suitable chemical compound (e.g. $\mathrm{KI}$ or $\mathrm{NaOH}$ )-acquires additional properties that allow hydrogen sulphide in the process of the removal through the alkalimetric acid/base reaction. ${ }^{17}$ As it has been proved, in the case of VMSs removal (except trimethylsilanol-TMSOH) on an impregnated filter, appropriately coated activated carbon has a lower adsorption efficiency and significantly decreases the filter efficiency. The most significant advantages of using carbon filters in commercial gas purification technologies are its low price, availability, and the low-cost process of its thermal regeneration. ${ }^{17}$ The following Table 6 presents the above described commercially used VMSs adsorbents and compares them with each other in terms of structure, polarity, porosity, specific surface area, and pore size.

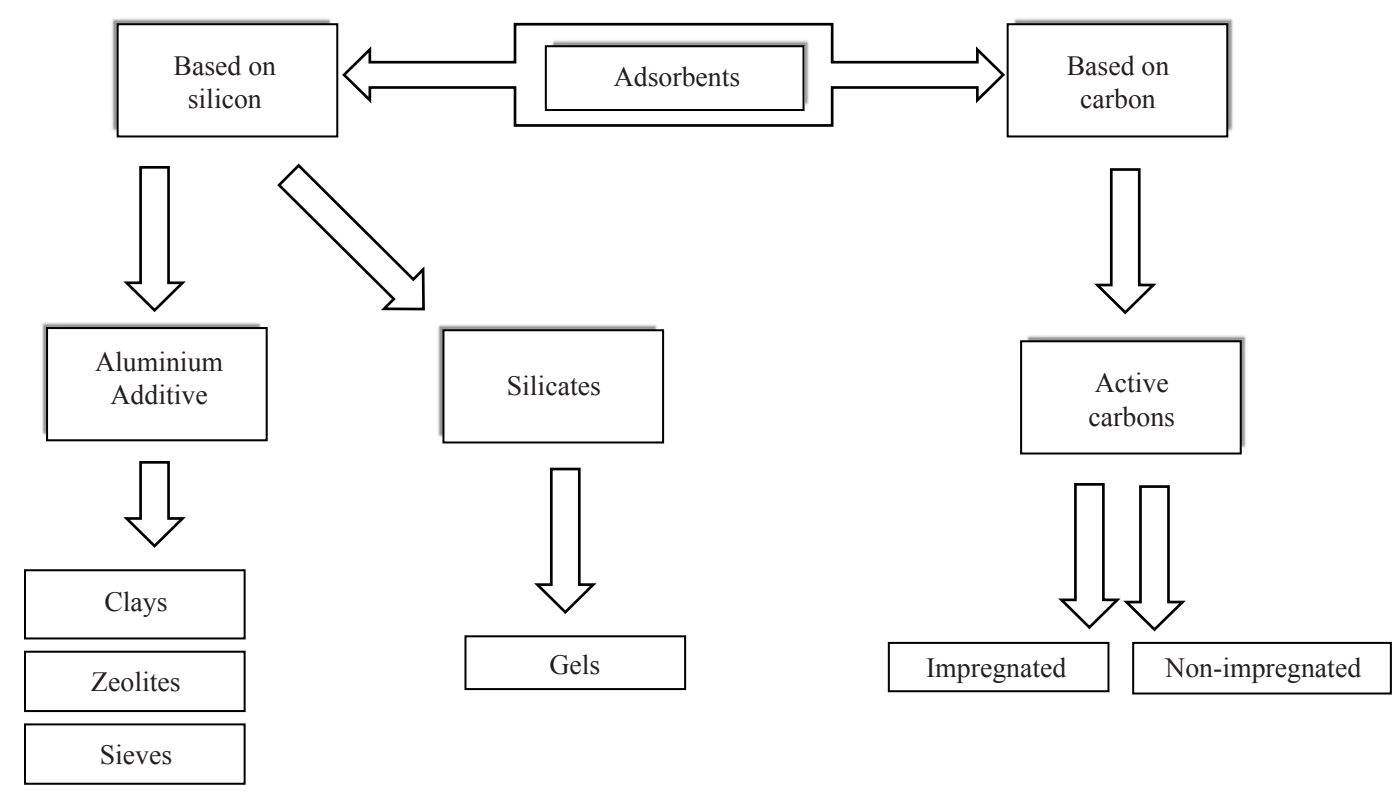

Figure 1. Division of VMS adsorbents according to their chemical structure

Table 6. Selected physical properties of VMSs adsorbents ${ }^{18}$

\begin{tabular}{ccccc}
\hline Adsorbent & $\begin{array}{c}\text { Structure } \\
\text { physical }\end{array}$ & Polarity & $\begin{array}{c}\text { Porosity } \\
(\%)\end{array}$ & $\begin{array}{c}\text { Specific surface area } \\
\left(\mathrm{m}^{2} / \mathrm{g}\right)\end{array}$ \\
\hline Silica gels & amorphous & polar & 70 & $\begin{array}{c}\text { Pore size } \\
(\mathrm{nm})\end{array}$ \\
Molecular sieves & crystal & polar & $40-50$ & $600-700$ \\
Active carbons & amorphous & non-polar & $55-75$ & $600-1600$ \\
\hline
\end{tabular}




\subsection{Removal of VMSs based on chemical and physical absorption}

The removal of VMSs based on the phenomenon of chemical absorption in a liquid medium has been attempted several times by different researchers. ${ }^{19}$ Chemical absorption of volatile methyl siloxanes from biogas based on the use of concentrated acids and alkalis has not yet proved to be an effective method for biogas cleaning. On the other hand, taking into account the chemical stability of the siloxane chain, the removal process of VMSs based on its direct dissociation (also in strong acids and bases) may not be efficient, given the high ionization energy of the Si-O.

\subsection{Removal of VMSs based on biological processes}

The removal of VMSs from biogas based on biological processes ${ }^{20}$ is an alternative to the methods commercially used in biogas treatment technology, however, the biodegradation method has several significant limitations that require further scientific and technological recognition. Although VMSs show relative resistance to chemical and biological degradation reactions, techniques are known for their removal based on biological processes. Laboratory biofilters are based on microorganisms living in the aquatic environment tj. Pseudomanas (P. aeruginoasa, P. fluorescens, P. Putida) Agrobacterium (A. radiobacter), Arthobacter or Fusarium oxysporium, whose main problem of their adaptation under technological conditions is the high flow rate and thus the very short contact time of the bacterial flora with the VMSs particles, allowing the initiation of degradation bioreactions. Laboratory biofilter-based methods indicate to remove a maximum of $50 \%$ of the total VMS load from the inlet biogas stream, assuming a very low biogas flow rate of typically more than the level of $0.5 \mathrm{l} / \mathrm{h}$. Most operations on the biological degradation of VMSs are based on the degradation of cyclic D3 or D4. Micro-organisms based biological degradation of decamethylcyclopentasiloxane where the final reaction product is silicic acid $\left(\mathrm{H}_{4} \mathrm{SiO}_{4}\right)$ and formaldehyde. The operation of the biofilter, however, has its significant limitations, representing a low level of performance for VMSs characterised by low solubility in water, which in fact represents a major barrier to the commercialisation of a technological biofilter solution for the removal of VMSs. As it has been confirmed by scientific studies, the removal efficiency of VMSs from biogas in biological processes can be significantly improved by enriching the biofilter with non-ionic substances, e.g. oleic alcohol. As it has been scientifically proven, in most cases the implementation of biofilters for VMS removal from biogas is still at the design stage, among which the biggest obstacle is to obtain high VMS removal efficiencies with full biogas process flows of up to $1000 \mathrm{~m}^{3} / \mathrm{h}^{20}$

\subsection{Removal of VMSs based on cryogenic condensation}

Cryogenic condensation is one of the methods where the deep chilling of biogas/biomethane was reported. Schweigkofler and Niessler ${ }^{19}$ investigated the siloxanes removal efficiency at $5{ }^{\circ} \mathrm{C}$ and over $88 \%$ of the initial siloxane concentrations remained. Hagmann et al., reported a cleanup efficiency for a range of volatile siloxanes of $25.9 \%$ when cooled down to $-25^{\circ} \mathrm{C}$. Rossol et al., operated deep chillers to remove siloxanes from sewage-sludge biogas at a working temperature of $-30{ }^{\circ} \mathrm{C}$ and reported elimination rates of $80 \%-90 \%$. ${ }^{22}$ As recent literature indicates, the Cryogenic Temperature Condensation System (CTCS) based on two chilling columns was tested and the siloxanes from the biogas stream were removed entirely. ${ }^{10}$ The temperature of the process on $-50{ }^{\circ} \mathrm{C}$ and the biogas flow is up to $100 \mathrm{dm}^{3} / \mathrm{h}$. The CTCS works in temperatures ranging from -50.0 to $+40.0{ }^{\circ} \mathrm{C}$ and formed condensate discharges automatically from internal parts of the column. ${ }^{10}$

\subsection{Other methods of VMSs removal from biogas}

The market demand for a simple, sustainable, and environmentally friendly method for the commercial efficient removal of volatile silicon compounds, which at the same time includes an economic optimum, is the basis for advanced research on biogas and the VMS contained therein. Research reports indicate several new ideas that, for the time being, still do not go beyond the laboratory environment.

One interesting alternative to physical processes involves processes using combustion reaction catalysts VMSs. A catalyst in the form of $\mathrm{V}_{2} \mathrm{O}_{5}$ adsorbed on $\mathrm{TiO}_{2}$ together with biogas heated to a temperature in the range of $250-400{ }^{\circ} \mathrm{C}$ allows for the removal of the silicon charge along with other organic impurities prior to direct feeding of the biogas to 
the unit. The only disadvantage of the combination used is the rapid wear of the catalyst, due to its surface coating with microcrystalline $\mathrm{SiO}_{2}$. Another way of removing VMSs in the form of D3 was to use catalysts in the form of oxides, i.e. $\mathrm{CaO}, \mathrm{MgO}, \mathrm{Al}_{2} \mathrm{O}_{3}$, however, the operation of the catalysts at $200-400{ }^{\circ} \mathrm{C}$ did not show significant removal efficiencies of VMSs. $^{23}$

Research carried out on membrane technology ${ }^{24}$ for the removal of VMSs is still in the laboratory testing phase, but it offers a real opportunity for implementation. The promising approach was conducted on the poly-dimethyl-siloxane membrane, which can be adopted for siloxanes (the membrane was tested on octamethyl tetrasiloxane) and VOC removal from biogas, but further tests should be led. ${ }^{25}$

Researches over methods of removing VMSs from biogas reveals three more completely new ways of cleaning biogas. The first of these is ultraviolet photodecomposition, ${ }^{26}$ in which silicon compounds are already removed from the production waste. The second method is based on peroxidation, ${ }^{27}$ where the removal efficiency of D4 and D5 is up to $50 \%$ and the third anode is solid oxide fuel cell anode degradation, ${ }^{28}$ however, the efficiency of Si-contaminants removal for proposed solutions was up to $25 \%$ or was more efficient for chosen types of siloxanes.

\section{Conclusion}

The conclusion was drawn from the work that biogas and biomethane are the energetic media that need to be cleaned from siloxanes before their utilization. Presently, the most common and applied in industry method of siloxanes removal is cleaning using active carbon filters. Moreover, further research should be focused on methods based on biological processes, membrane separation, catalytic reactions, peroxidation, or anode degradation with taking into account the selectivity of siloxanes, thus it depends on biogas origin. An improvement for purification technology based on effective siloxanes removal systems is central to protect CHP units and gas grids as well as upgrade the biogas to biomethane quality.

\section{References}

[1] Piechota, G.; Iglinski B. Biomethane in Poland-current status, potential, perspective and development. Energies 2021, 14, 1517.

[2] Polish Norm ST-IGG-3501: 2019. Quality and technical requirements for biomethane injected into a distribution network, Part 1. 2019.

[3] Pilarski, G.; Kyncl, M.; Stegenta, S.; Piechota, G. Emission of Biogas from Sewage Sludge in Psychrophilic Conditions. Waste Biomass Valor. 2020, 11, 3579-3592.

[4] European Biogas Association. 2019 Annual Report. https://www.europeanbiogas.eu/wp-content/uploads/2020/01/ EBA-AR-2019-digital-version.pdf (accessed Jun 25, 2021).

[5] Paolini, V.; Petracchini, F.; Carnevale, M.; Gallucci, F.; Perilli, M.; Esposito, G.; Segreto, M.; Galanti Occulti, L.; Scaglione, D.; Ianniello, A.; Frattoni, M. Characterisation and cleaning of biogas from sewage sludge for biomethane production. J. Env. Manage. 2018, 217, 288.

[6] MWM, Jenbaher, MTU, MAN. Technical Handbooks-“Biogas Reqirements”. 2018.

[7] Piechota, G.; Igliński, B.; Buczkowski, R. Development of measurement techniques for determination main and hazardous components in biogas utilized for energy purposes. Ener. Conv. Manage. 2013, 68, 219-226.

[8] Pioquinto García, S.; Garza Rodríguez, L. A.; Bustos Martínez, D.; Cerino Córdova, P.; Regalado, E. S.; Giraudet, S.; Dávila Guzmán, N. E. Siloxane removal for biogas purification by low cost mineral adsorbent. J. Clean. Prod. 2021, 286, 124940.

[9] Paolini, V.; Petracchini, F.; Segreto, M.; Tomassetti, L.; Naja, N.; Cecinato, A. Environmental impact of biogas: A short review of current knowledge. J. Envi. Sci. Health. 2018, 53, 899-906.

[10] Piechota, G. Removal of siloxanes from biogas upgraded to biomethane by Cryogenic Temperature Condensation System. J. Clean. Prod. 2021, 308, 127404.

[11] Kusrini, E.; Wu, S.; Susanto, B. H.; Lukita, M.; Gozan, M.; Hans, M. D.; Rahman, A.; Kymäläinen, M.; Lähde, K.; Arnold, M.; Kurola, J. M.; Romantschuk, M.; Kautola, H. Biogasification of biowaste and sewage sludgeMeasurement of biogas quality. J. Env. Manage. 2012, 95, S122. 
[12] Piechota, G. Siloxanes in biogas: Approaches of sampling procedure and GC-MS method determination. Molecules. 2021, 26, 1953.

[13] Ajhar, M.; Travesset, M.; Yüce, S.; Melin, T. Siloxane removal from landfill and digester gas-a technology overview. Bioresour. Technol. 2010, 101, 2913.

[14] Gao, R. L.; Cheng, S. K.; Li, Z. F. Research progress of siloxane removal from biogas. Int. J. Agric. \& Biol. Eng. 2017, 10, 30.

[15] Matsui, T.; Imamura, S. Removal of siloxane from digestion gas of sewage sludge. Bioresour Technol. 2010, 101, S29.

[16] Gaj, K. Adsorptive biogas purification from siloxanes-a critical review. Energies 2020, 13, 2605.

[17] Piechota, G. Multi-step biogas quality improving by Adsorptive Packed Column System as application to biomethane upgrading. J. Env. Chem. Eng. 2021, 9, 105944.

[18] Mycock, J. C.; McKenna, J. D.; Theodore, L. Hendbook of Air Pollution Control Engeneering and Technology; FL: CRC Press, Boca Raton, 1995.

[19] Schweigkofler, M.; Niessner, R. Removal of siloxanes from biogases. J. Hazard. Mater. 2001, 83, 183.

[20] Accettola, F.; Gübitz, G.; Schöftner, R. Siloxane removal from biogas by biofiltration. Clean Technol. Env. Policy. 2008, 10, 211.

[21] Hagmann, M.; Hesse, E; Hentschel, P. Purification of biogas-removal of volatile silicones, $8^{\text {th }}$ International Waste Management and Landfill Symposium, Sardinia: CISA, 2021; pp 641-644.

[22] Rossol, D.; Schmelz, K. G.; Hohmann, R. Siloxane im Faulgas. KA-Abwaser Abfall 2003, 8, 8.

[23] Finocchio, E.; Garuti, G.; Baldi, M.; Busca, G. Chemosphere. 2008, 72, 1659.

[24] Nyamukamba, P.; Mukumba, P.; Chikukwa, E. S.; Makaka, G. Biogas upgrading approaches with special focus on siloxane removal-a review. Energies 2020, 13, 6088.

[25] Favre, E.; Bounaceur, R.; Roizard, D. Biogas, membranes and carbon dioxide capture. J. Membr. Sci. 2009, 328, 1-2, 11-14.

[26] Divsalar, A.; Sun, L.; Dods, M. N.; Divsalar, H.; Prosser, R. W.; Egolfopoulos, F. N.; Tsotsis, T. T. Feasibility of siloxane removal from biogas using an ultraviolet photodecomposition technique. Ind. Eng. Chem. Res. 2018, 57, 7383.

[27] Appels, L.; Baeyens, J.; Dewil, R. Energy Convers. Manage. 2008, 49, 2859.

[28] Madi, H.; Lanzini, A.; Papurello, D.; Diethelm, S.; Santarelli, C. L. M.; Van herle, J. Solid oxide fuel cell anode degradation by the effect of hydrogen chloride in stack and single cell environments. J. Power Sour. 2016, 326, 349. 